\title{
The potential exploitation of non-English-speaking players in UK professional football contracts
}

\author{
Alexander Brown ${ }^{1}$ (D) - Roger Baines ${ }^{1}$
}

Published online: 15 January 2019

(c) The Author(s) 2019

\begin{abstract}
The article asks whether English professional football clubs have the potential to exploit non-English-speaking players during contract negotiations and signing meetings. We draw on evidence we gathered from a series of semi-structured interviews with football agents, former migrant players, and player liaison/welfare officers who currently work or have previously worked in English professional leagues. We also draw on normative insights from legal, moral, and applied ethical thought to develop a new, bespoke account of what should shock the conscience of the court. We argue that because of language barriers, non-English-speaking players could end up signing unconscionable contracts, if not based on procedural or substantive unfairness, then potentially based on violations of their autonomy through deceptiveness. We also show that the current practice of players' agents acting as ad hoc translators/interpreters raises serious ethical issues, not least lack of competency and impartiality. Following on from all this, we make a number of practical recommendations about how players' representatives and clubs should conduct themselves, and what responsibilities they have to provide language support to non-English-speaking players in contract negotiations and signing meetings.
\end{abstract}

Keywords Applied ethics · English language proficiency · Translation/interpreting · Professional football · Unconscionable contracts

\section{Introduction}

Professional sport raises numerous issues of fairness, and football is no different: everything from the fairness of players simulating being fouled, ${ }^{1}$ to financial fair play rules, ${ }^{2}$ and onto fairness in the distribution of prize money. ${ }^{3}$ This article is concerned with the question of whether English professional football clubs have the potential to take unfair advantage of, that is, exploit, non-English-speaking players during contract negotiations and signing meetings. To date, the literature on exploitation in professional sports has touched on various contexts of exploitation, including exploitation by professional sports organisations of professional sportspeople, ${ }^{4}$ of fans, ${ }^{5}$ and even of non-professional sports organisations which develop young talent. ${ }^{6}$ Our focus

Alexander Brown

alexander.c.brown@uea.ac.uk

Roger Baines

r.w.baines@uea.ac.uk

1 University of East Anglia, Norwich Research Park, Norwich NR4 7TJ, UK is the particular issue of whether English professional football clubs have the potential to exploit migrant non-Englishspeaking players before a ball is even kicked. ${ }^{7}$

We shall discuss cases where negotiations are conducted and contracts written, in English, despite the fact that the player's ability to comprehend, speak, or read English is limited or non-existent. These include: (1) cases where the representative (intermediary or agent) who has brought the player to the UK has some English language ability and relays in translation what the player needs to know; (2) cases where the representative has little or no facility in the English language and is unable to translate the negotiations and

\footnotetext{
1 Loland (2015).

2 Schubert and Lopez Frias (2017).

3 Brown (2015).

${ }^{4}$ See Wertheimer (1996), ch 3; Mcnamee (2010), part 6.

5 Kennedy and Kennedy (2016), p. 64.

${ }^{6}$ Corlett (2013).

${ }^{7}$ We shall not discuss here further questions about the possible exploitation of non-English-speaking players at the point when they are playing for professional clubs, such as in terms of failures to provide English language training.
} 
the contract for the player without, for example, recourse to automatic translation software (e.g. Google Translate); and (3) cases where the player has an entourage of five or more representatives, all of whom speak some English as a second or third language, but all of whom have different interpretations of the wording of the negotiations and the contract. We are especially interested in cases involving players coming to English clubs from countries-including both developing countries in Africa or Latin America and other European countries-where English is not an official language, is not a lingua franca, or is typically not used by poorer, less educated people.

Although we focus on migrant non-English-speaking players, we compare their situation to English-speaking players throughout. We consider the ethical implications of contracts containing harsher terms or lower salary offers for players with little or no knowledge of the English language, compared to their more fluent counterparts. And we consider the ethics of non-English-speaking players being unable to understand negotiations and read contracts and, therefore, being more dependent on representatives in comparison with English-speaking players, whether or not the contracts actually contain similar terms and salary offers. Along the way, we also explore the actions of representatives themselves in potentially facilitating exploitative contracts and the ethical issues raised by individuals fulfilling the dual role of player representative and unqualified interpreter.

The remainder of the article unfolds as follows. Section 2 provides a picture of the current state of play in the negotiation and signing of English professional football contracts vis-à-vis the position and treatment of non-English-speaking players. The information derives from a series of semi-structured interviews with football agents, former migrant players, and player liaison/welfare officers who currently work or have previously worked in English professional leagues. These interviewees were asked about language support in the football industry, including the negotiation and signing of contracts. ${ }^{8}$ Whilst there has been considerable evolution in the awareness of the need to provide language support to migrant players during a period of initial adaptation to working in a new country, this is most in evidence at the higher end of the leagues, especially in clubs which have been established in the English Premier League for a number of years. Practices are much more patchy and ad hoc elsewhere, and this is reflected in the ways in which communication

\footnotetext{
${ }^{8}$ Although similar issues are likely to be faced by professional female migrant players, the percentage of such players working in England is much smaller (19.5\%) than the percentage of male migrant players $(69 \%)$, so we have focussed on male players. UEFA, 2016, Women's football across the national associations 2016/2017, available at: http://www.uefa.com/insideuefa/football-development/women s-football/news $/$ newsid $=2431355 . \mathrm{html} \# /$, consulted 17 December 2017.
}

across language barriers can be managed in contract negotiations and signings.

Following on from this, we attempt to justify our belief that there could be in some cases something exploitative about English professional football contracts signed by nonEnglish-speaking players, drawing on insights from legal, moral, and applied ethical thought.

In Sect. 3, we look at the legal doctrine of unconscionable contracts-including but also going beyond the relevant case law-and, more specifically, the notion of exploitation of weakness. We argue that this legal notion, once developed and strengthened, is clearly applicable to English professional football contracts signed by non-English-speaking players.

In Sect. 4, we draw on work in the field of normative jurisprudence to develop a new, bespoke account of what sorts of procedural and substantive unfairness, what forms of ignorance, and what types of violation of autonomy through deceptiveness, should shock the conscience of the court. We argue that these insights and developments provide the bases for robust and normatively fitting jurisprudential analyses of how English professional football contracts signed by nonEnglish-speaking players could be unconscionable.

In Sect. 5, we consider the ethically prior question of what an appropriate allocation of primary and secondary responsibilities for providing language support to nonEnglish-speaking players looks like. Taking note of recent developments in applied ethics (e.g. legal profession ethics, sports representative ethics, business ethics, interpreter ethics, translation ethics), we examine these issues from the standpoint of players, players' representatives, professional clubs, national football associations, and players' unions or professional players' associations. We put forward a new theory according to which primary and secondary responsibilities for providing language support during contract negotiations and signing meetings should be allocated according to both capacity and the existence of fiduciary relationships.

In Sect. 6, we contextualise the interpreted event of the negotiation of the contract between club, player, and player representatives, and of any discussion of the contract when it is physically signed, with interpreting in other professional settings. We also discuss some of the ethical issues raised by the use of an unqualified person or persons fulfilling a dual role of interpreter and player representative. Moreover, we briefly provide some thoughts on why clubs might behave as they currently do, but also why there are good economic and business reasons, as well as normative reasons, to do better.

Finally, in Sect. 7 we make a range of practical recommendations, based on our legal, moral, and ethical reasoning, about how clubs and players' representatives should conduct themselves, and what responsibilities they have to provide language support to non-English-speaking players in contract negotiations and signing meetings. 


\section{The state of play in English professional football contracts vis-à-vis language support}

There has been considerable migration of professional footballers into English professional leagues over the past 20 years or so, to the extent that, in the 1995-1996 season, $69 \%$ of English Premier League players were English but in 2017-2018, only 31\% were English with the remaining 69\% sharing 65 different nationalities. Migration levels have also increased in the Championship where over $50 \%$ of players were migrants in 2017-2018, more than in the highest German league, the Bundesliga. ${ }^{9}$ The linguistic diversity created by the presence of these elite migrant players has created a need for translation and interpreting ${ }^{10}$ and a slowly developing awareness that these players need language support. ${ }^{11}$ Such support can be needed not simply during the period of employment (e.g. media interviews, interactions with a manager/coach, processes of finding accommodation and understanding tax requirements), and it is also needed during the negotiation and signing of the contract. The latter will be our focus here.

In theory, language support could be delivered by clubs through the work of player liaison/welfare officers, by outsourced concierge or translation and interpreting services, or in an ad hoc way by particular employees of the club, such as physiotherapists or coaches who share the player's first language. Such language support can also be secured independently of the club by the player, or the player's representative. Sometimes it is simply absent.

Much practice around negotiating and signing the contract is undoubtedly conducted professionally, especially at the higher levels where migrant players coming to live and work in England will often have the language support they need. There is nonetheless evidence of some less professional practice, and we shall normatively evaluate this in the following sections. We will also discuss in Sect. 6 the common use of players' agents, intermediaries, or lawyers in the dual role of players' representatives and unqualified

\footnotetext{
${ }^{9}$ Sky Sports, 2017, Premier League has highest percentage of foreign players-UEFA report, available at: http://www.skysports.com/ football/news/11661/10725849/premier-league-has-highest-perce ntage-of-foreign-players-8211-uefa-report, consulted 12 December 2017.

10 Baines (2013).

11 Such awareness has perhaps been slow to develop, first, because football clubs and the sport's institutional bodies have been traditionally slow to modernise, run as they have often been by people from within the industry domestically rather than by individuals with a more intentional outlook and familiarity with operating internationally, and, second, because governance and leadership in football is notoriously prone to instability. Either way, arguably such awareness should be an issue of corporate responsibility in football. See also Rosca (2011).
}

interpreters as one particular practice that raises professional ethical issues. But to anticipate slightly, the following two comments from agents operating in the English leagues show how minimal the emphasis can be on professionally communicating to the player the terms of the contract he is signing:

This is a particularly incredible area really [...] at times it can be quite ethically challenging because I've yet to come across a football club ever that was willing to provide a translation of the paperwork that is being signed. I am expected to do my best at explaining to the player the effect of what they're signing but the reality is a transaction, even this would apply down in League Two, is at least 60 or 70 pages worth of documents that they're being presented with, sometimes at the high level hundreds of pages. I'm expected to explain to the player the effect of what they're signing and satisfy myself that they understand. I've seen agents and players sign the documents within $30 \mathrm{~s}$ of them being presented to them and that player has no idea what he's signing. ${ }^{12}$

It was down to me to check the agreement [...] I didn't have massive resources nor did the club I was working for, because they're on a lower scale but we were dealing with a player who didn't speak English, didn't speak German, and we were dealing with agreements in both English and German. So I had to translate the German on the spot using automated translation to get some form of interpretation of it. It's quite dangerous and the player's trust is totally in the people around him and there's a lot of people who will prey on him. ${ }^{13}$

\section{Unconscionable contracts}

As part of this research project, we undertook a survey of cases heard at the Court of Arbitration for Sport and cases heard in courts in England and Wales involving football contracts. We found no cases of players challenging the legality of contracts on the grounds that the player lacked English language facility even though the contract was written in English and the contractual negotiations were conducted in English. The absence of such cases may be due to a culture of players not attempting to sue clubs for fear that doing so could damage their careers or harm their prospects going forward, not least because a player might not be able to play for the club whilst pursuing an action which could take years to reach its resolution. It may also reflect legal advice given to players that their lack of English language facility per se

\footnotetext{
12 Football Agent 1.

${ }^{13}$ Football Agent 3.
} 
does not currently fall into an established category of any recognised cause of action, or legal doctrine.

Even though the law is currently silent on these specific sorts of circumstances, in this section we shall nonetheless look at some of the potentially relevant causes of action and related case law to identify the sorts of cases that in theory players could bring. More importantly, in the next section we shall use methods in normative legal philosophy to argue that certain established categories of recognised causes of actions, specifically relating to the doctrine of unconscionable contracts and the associated legal concepts of procedural and substantive unfairness and moral reprehensibility, should be freshly analysed, in ways that would, if adopted by courts, open up the possibility of players bringing such cases in the future.

We begin, however, by discounting two other legal doctrines. The first is contractual incapacity. This typically requires that one of the parties has a cognitive inability to understand the contract, even if it were properly explained in a language he speaks. Instead, we are interested in cases where a lack of understanding is caused by an absence of English language proficiency.

The second is non est factum. This can be invoked if the substance of a contract is fundamentally different from what one of the parties intended to execute or sign. Assuming that a player has a basic grasp that they are signing a contract to be a professional footballer at an English club, it is unlikely that a court would accept that the contract is fundamentally different from what the player thought he was signing, even if the player cannot read or understand English.

Of more likely relevance, we think, is the doctrine of unconscionable contract. According to Andrew Burrows, for instance, this doctrine is used 'to protect the claimant against a weakness (whether a mental weakness or one arising from the claimant's difficult circumstances) ${ }^{,}{ }^{14}$ albeit 'the weakness is not so extreme as to constitute incapacity.'.15

Weakness alone is not enough, however. A contract becomes unconscionable only if one party takes advantage of a weakness (a procedural element) in order to get the other party to enter into a contract which is significantly weighted against the interests of the latter (a substantive element), and in a way that offends or shocks the conscience of the court. In other words, it must be demonstrated that one party achieved a one-sided or unfair bargain because it exploited a weakness, and in a morally reprehensible manner according to the norms of the society. ${ }^{16}$

What does the test of moral reprehensibility add? One potential way to conceive of this-moving beyond but we

\footnotetext{
14 Burrows (2011), p. 300.

15 Ibid.

16 Burrows (2011), ch 12; (2016), ch. 15.
}

hope also enhancing the extant case law-is in terms of the stronger party having knowledge, actual or constructive, of the other party's weakness. This means either that A knows of B's weakness (actual knowledge) or that A would have known of B's weakness had A taken proper steps to try to know it (constructive knowledge). For instance, if A had suspicions, or can be reasonably expected to have concerns, as to the fact of B's weakness, yet deliberately decided not to make any further enquiries, then A can be said to have had constructive knowledge of B's weakness (even if A lacked actual knowledge). Following on from this general line of thinking, in the next section we propose a new analysis or test for 'a morally reprehensible manner' of exploiting a weakness based on the occurrence of deceptiveness and damage to the value of autonomy (in making contracts). However, we begin with a discussion of the link between the idea of exploiting a weakness and the idea of unequal bargaining power.

According to Burrows, judges and legal scholars have sometimes used the terms 'unequal bargaining power' and 'unconscionability' interchangeably. ${ }^{17}$ The nature and form of this weakness can vary according to the circumstances of the case. In Lloyds Bank Ltd v. Bundy, ${ }^{18}$ for example, Lord Denning sets out the following categories of weakness: 'the English law gives relief to one who, without independent advice, enters into a contract on terms which are very unfair or transfers property for a consideration which is grossly inadequate, when his bargaining power is grievously impaired by reason of his own needs or desires, or by his own ignorance or infirmity, coupled with undue influences or pressures brought to bear on him by or for the benefit of the other'. ${ }^{19}$ Arguably Denning made the statement in the context of seeking to draw a link between many vitiating factors, almost seeking to create a new doctrine of inequality of bargaining power.

Interestingly, the foregoing lines of jurisprudential thinking about weakness have also emerged in the wider context of lawsuits in the entertainment industry (of which sport is a part). Consider the House of Lords judgments in Schroeder v. Macaulay ${ }^{20}$ and Clifford Davis Management Ltd v. WEA Records $L t d,{ }^{21}$ a case involving Fleetwood Mac. In both cases, musicians were released from contracts which contained onerous terms in the context of inequality of bargaining power. $^{22}$

\footnotetext{
17 Burrows (2011), p. 301; (2016), p. 835.

18 Consider Lloyds Bank v. Bundy [1974] 3 All ER 757 at 763 (Lord Denning).

19 Ibid., at 765 .

20 [1974] 1 WLR 1308.

21 [1975] 1 All E.R. 237.

22 Slayton (1976).
} 
Over time new categories of weakness have emerged of particular relevance to our enquiry, most notably cases of language and comprehension difficulties. ${ }^{23}$ In Portman Building Society v. Dusangh and others, ${ }^{24}$ for instance, the court considered a case of a signatory to a remortgage contract who had come to England from India in 1964 and, despite being resident for many years, at the time of signing the contract had poor understanding of spoken English and was illiterate. Ultimately the Court of Appeal concluded that Dusangh had understood the contract because he had grasped to a sufficient degree the verbal explanations he had received. Nevertheless, courts in the USA have accepted the offeree's inability to read the language in which the contract was written as meeting the requirements of an unconscionable contract (exploitation of weakness) if discrepancies exist between what was presented to the offeree during the contractual negotiations conducted in the offeree's mother tongue and what was actually contained in the contract written in a language the offeree does not understand. ${ }^{25}$

What of sports contracts? That such contracts can be unconscionable is not a new proposition. In the legal dispute between Rory McIlroy and Horizon Sports, for example, applications were sent to the Commercial Court in Dublin in 2013 by McIlroy's lawyers-prior to the case being settled out of court-in which they invoked the doctrine of unconscionable contract. They highlighted the size of the percentage of on course and off course earnings being paid to the management company (substantive element), and the weakness of McIlroy at the time of the contract due to his age, and having no independent legal and financial advice on hand at the time of signing the contract, namely the day of Horizon's Christmas party (procedural element). ${ }^{26}$ More recently, Bryant Lee has applied the doctrine of unconscionable contract to college football scholarships in the USA, arguing inter alia that because these scholarships involve young American football players being put at significant risk of traumatic brain injury this makes the bargain 'too harsh' or 'one-sided' and, therefore, unconscionable. ${ }^{27}$ The doctrine of unconscionable contracts has also been discussed in some of the philosophical literature on exploitation in sport. $^{28}$

Drawing on these developments in the doctrine of unconscionable contracts, it is not difficult to see how a player's

\footnotetext{
${ }^{23}$ Burrows (2016), pp. 842-4.

24 [2000] All ER (D) 582.

25 Consider Frostifresh Corp. v. Reynoso, 52 Misc.2d 26 (N.Y. Misc. 1966), at 27; Albert Merrill School v. Godoy, 78 Misc.2d 647 (1974), at 650 .

26 This case is cited in Barry et al. (2016, 157-8).

27 Lee (2017).

28 Wertheimer (1996), ch 2.
}

inability to speak, comprehend, or read English could make some English professional football contracts unconscionable. To be clear, we believe the doctrine is applicable not only to facts about the language in which the negotiations were conducted but also to facts about the language in which the contract was written-facts including the absence of professional translators and translations.

We also believe that the idea of a stronger party acting in a morally reprehensible way in virtue of knowingly taking advantage of the other party's weakness in order to achieve a one-sided bargain is highly relevant to some English professional football contracts involving non-English-speaking players. In the case of actual knowledge, a court can ask: Did the club know the player lacked even basic facility in the English language? In the case of constructive knowledge, it can ask: Would the club have known that the player lacked this facility had it taken reasonable steps to find out?

We also recognise that when professional clubs leave players' representatives to look after the interpreting of the negotiations and signing meetings, they can unwittingly leave space for the agent to manipulate the proceedings, potentially to the advantage of the agent and to the detriment of the club and the player.

\section{The moral reprehensibility of unconscionable contracts}

The account of exploitation of weakness outlined above speaks to what would shock the conscience of the court, cashed out in terms of certain classes of cases or categories identified by precedent. However, are there any moral reasons for thinking that courts ought to recognise language deficit as a category of unconscionable contract? After all, the Human Rights Act 1998 declares the right to free assistance of an interpreter in court settings. In other words, could there be a rational basis for courts judging that a language deficit constituted unequal bargaining power (the procedural element) and that the resulting bargain was significantly onesided or harsh (substantive element) under circumstances worthy of shocking the conscience of the court? In this section, we are going beyond actual case law to give a normative jurisprudential analysis of what contract law could and should say in the cases we are looking at.

We shall begin by enquiring whether English professional football contracts signed by non-English-speaking players could be substantively unconscionable. It might be especially important to determine this in cases where it is difficult to discover what happened during the negotiations and, therefore, hard to determine whether there was any unequal bargaining power (procedural element). Sometimes courts might be unable to get to the bottom of just how much English language facility the player had or just how much of 
the contractual negotiations and the contract was translated into a language the player could understand. Here, as Alan Wertheimer has suggested, the substantive unconscionability of the bargain could be utilised as 'a proxy for procedural unconscionability in the face of the epistemological problems'. ${ }^{29}$

We assume that in order to make a non-arbitrary assessment of substantive unconscionability courts will need to light upon an independent criterion of fairness that does not prejudge the issue. But this may be easier said than done. Consider the terms of the contract. Suppose a non-Englishspeaking player signs a 1-year deal which includes an option clause allowing the club to unilaterally extend the contract a determined number of times, for a determined number of years, and with a determined (modest) increase in salary. Option clauses enable clubs to take calculated risks on unproven players, with the expectation that some players will work out but many will not. It strikes us as highly unlikely that an English court would adopt a criterion of fairness which stipulates that all option clauses are one-sided or too harsh. For one thing, section C.1. (j) (xiii) of the Rules of the Football Association Limited (the FA rules) vindicates option clauses (with certain provisos). Moreover, in England option clauses are commonplace in standard form players' contracts, which themselves can be viewed as a product of some degree of collective bargaining between the Professional Footballers' Association (PFA) and professional clubs. ${ }^{30}$ To be sure, the legality of contracts of employment in professional football is sensitive to English common law, ${ }^{31}$ but English courts would require a very powerful reason to adopt a blanket ruling against option clauses in the face of the aforementioned FA rules and de facto collective bargaining.

In reality, there are some good reasons not to treat option clauses as contractual pariahs. When clubs sign players, they do so based on predictive expectations of future performance levels - reflecting assessments of the player's past performance and estimations of how well the player will adapt to the club's training methods and playing style. Different players are more or less risky investments for football clubs given myriad factors relating not only to physical and mental skills, talents, traits, and dispositions, but also to personal circumstances such as age, marriage status, family background, country of origin, and level of education. This means the salary and the terms offered to a player who has tremendous potential but is also a risky prospect-suppose only 1 in 10 of players of this sort fully realise their

\footnotetext{
${ }^{29}$ Wertheimer (1996), pp. 54-55.

30 O'Leary (2017), p. 208.

31 See, for example, Eastham v. Newcastle United Football Club Ltd and Others [1963] 3 All ER 139.
}

potential-are unlikely to be the same as are offered to a player who has to some extent already realised their potential. The level of risk exposure to the club is inevitably reflected in the substance of the contract-in the salary or in the terms or both. A club might offer a 1-year contract to an unproven player on a relatively favourable salary, but in order to reflect the level of risk the club might include an option clause. Thus, although the option clause might seem one-sided or harsh taken in isolation, overall the contract might not be one-sided or harsh if one also considers the salary and the risk. ${ }^{32}$

More importantly for our study, option clauses are not peculiar to contracts signed by players coming to English clubs from abroad and who do not speak English. As indicated by Football Agent 1, option clauses seem to be a fixture of contracts offered to younger players across the board. If the terms offered in standard form English professional football contracts are precisely that, standard, then at first glance non-English-speaking players would not have any greater or lesser cause to complain that their contracts are substantively unfair than their English-speaking counterparts.

Then again, perhaps substantive unconscionability could stem from the greater burdens and risks borne by non-English-speaking players due to circumstances contingently connected with their language deficit. Consider a player who is recruited from Latin America. In moving to an English club, he carries the burden of a change in climate, culture, and lifestyle which may not be to his liking. Due to visa restrictions, he might be unable to immediately—or ever-bring with him certain family members. Then there is the risk of a crushing sense of failure (psychic damage) in circumstances where the player leaves his home and travels half way around the world to start a new life in England only to be told after 1 year that he has not made the grade. If his visa is connected to his employment, he may then have to leave the country: a further upheaval. Thus, even if similar terms are offered to migrant, non-English-speaking players-such as option clauses - this belies extra levels of burden and risk shouldered by such players.

However, rational judgements as to the substantive unconscionability of contracts must always take into consideration the terms, the salary, and the risk on both sides. And so it is possible that the salary offers made by English clubs to migrant, non-English-speaking players make up for the extra burdens or risks those players must bear. Indeed, it could be that if courts adopt a criterion of fairness that compares what migrant, non-English-speaking players expect to gain from the contracts (against a baseline of having no contract or receiving the average salary of professional football players in their own countries) with the clubs' expected

\footnotetext{
$\overline{32}$ Wertheimer (1996), pp. 55-58.
} 
gains (against a baseline of only signing English-speaking players), it could be that the gains are broadly equal and so the contracts are not substantively unconscionable.

Nevertheless, an alternative way of thinking about substantive unconscionability is in terms of whether the club's salary offer was miserly by comparison with the club's normal salary offer for such a player or by comparison with the going rate for such a player in the market-as opposed to comparing what the player and the club each gained. Once again, however, determining the club's normal salary offer or the going rate in the market may not be straightforward. For one thing, there is the problem of establishing the right cohort of comparison. There should be no simplistic comparisons between the salaries of non-English-speaking players and English-speaking players for at least two reasons. First, due to circumstances contingently connected with a player being unable to speak English-such as the player coming from a developing country-clubs are likely to face higher administrative costs in identifying, scouting, and negotiating with non-English-speaking players. Second, English language proficiency could both directly and indirectly impact the player's expected performance level. Consider the player's coachability, leadership skills, contribution to team spirit, ability to settle into the wider community, marketability, and aptitude for handling media duties and work in the local community. ${ }^{33}$ For both of these reasons, a player's lack of English language facility will probably be one factor-even if not the key factor-in determining the going rate for the player. As a result, offering a lower salary to non-English-speaking players compared to otherwise equivalent English-speaking players might not be substantively unfair or unconscionable.

The technical challenges of making fair comparisons between players' salaries do not end there, however. Even discounting simplistic comparisons between the salaries of English-speaking and non-English-speaking players, it could be that each individual player possesses a skill set so unique that it is impossible to compare any two players, even two non-English-speaking players. In that event, there is no such thing as what the club normally pays for a certain type of player, only what the club is actually willing to pay at a given moment in time for a particular player. Furthermore, even if it is possible to compare players of broadly similar types (skill sets), it could be that there is a very wide margin of error over the going rate in the market, meaning that it becomes difficult to ascertain if a salary offer really is excessively or disproportionately below the going rate. It could be that the going rate is so wildly fluctuating over time that

\footnotetext{
${ }^{33}$ Even if a club also plans to invest in English language training for that player, it cannot be certain in advance how the player will respond to that training and how quickly.
}

even comparing today's price for a player with a certain skill set with yesterday's price is impossible.

Notwithstanding these technical challenges, courts might adopt the pragmatic rule that a contract is substantively unfair or unconscionable only if it grossly underpays a player by comparison with the going rate for such a type of player. But this still leaves plenty of ambiguity. Maybe a court should not be shocked if a club pays a particular non-English-speaking player slightly less than the going rate for equivalent non-English-speaking players, yet shocked if the non-English-speaking player receives significantly less. However, it may appear arbitrary the point at which a salary below the going rate becomes sufficiently below the going rate as to offend the conscience of the court. That being said, one solution would be for a higher court to establish a clear precedent according to which an English professional football contract is substantively unconscionable only when the player is paid not even half the going rate for his services. In justifying this move, the court could appeal to the Roman law injury of laesio ultra dimidium vel enormis ('loss beyond half or greater'). In this way, it is theoretically possible, we believe, for a court to non-arbitrarily determine that a contract is substantially unfair because the salary is grossly below the going rate.

Even assuming that the foregoing problems are not insurmountable, there remains the task of identifying an independent moral criterion to determine whether the parties have met on unequal terms or with unequal bargaining power (the procedural element). Bargaining power normally means the comparative ability of each party to exert influence on the other party, such as to drive upwards or downwards the terms offered by the other party, based on the comparative cost or burden to each party of an agreement not being reached. In layman's terms, the club might have higher bargaining power relative to the player if the club is the only club offering the player a contract and if the club has other players of similar quality it could sign.

However, it is not immediately obvious why a language deficit on the part of the player in itself would constitute an unequal bargaining position. An unequal or weak bargaining position is not the same as a weakness in the ability to comprehend the negotiation as it unfolds. After all, it is not difficult to imagine scenarios in which a player is unable to speak the language of the negotiation yet nevertheless enjoys a higher bargaining power relative to the club, such as if the player has uncommon or exceptional talent, has offers on the table from several clubs, plays a position on the pitch that the club is desperate to fill, and so forth.

However, it might be appropriate or fitting for courts, in such cases, to think about not only bargaining power in the above sense but also bargaining capacity. This is a matter of whether or not the parties to the contract have equal capacity, skill, expertise and so on, in negotiating the 
terms of the contract. For example, does one of the parties have significantly less bargaining capacity in terms of providing and articulating reasons, arguments and persuasive considerations as to why they should receive a better deal than is currently being offered? This could happen if, for instance, the negotiations are being done in English and the player does not speak English. He is then reliant on the agent to have bargaining capacity on his behalf. But what if the agent is not fluent in English, or is not fluent in the player's language? These circumstances could diminish the bargaining capacity of the player and/or his agent, thus creating another form of procedural inequality besides strict unequal bargaining power. In this way, we are proposing or suggesting a particular future development of the doctrine of unconscionable contracts that speaks to the types of cases we are interested in.

Furthermore, even sticking within the framework of unequal bargaining power, in the case of non-English-speaking players this unequal bargaining power could be understood in terms of other circumstances contingently connected with their language deficit. For example, an important bargaining chip for migrant players coming into English football is interest from other European clubs. Yet this depends on the player being on the radar of a range of clubs, which in turn reflects the level of football infrastructure in the player's home country, including the number of professional clubs, how many youngsters are playing at grass roots level, the strength of national football associations, players' unions, and so on. If the player lives in a country where very few European clubs regularly send scouts, then the player is more likely to end up with a single offer on the table, if he is lucky. If the player wants to go professional, he has no real alternative but to accept whatever non-negotiable terms are offered. $^{34}$

However, unconscionable contracts also require that the unequal bargaining power brought about a substantively unfair or unconscionable bargain. No matter how unequal the bargaining power, it would be far more difficult to sustain the charge that a contract is unconscionable, morally and legally, in the absence of evidence that the terms of the bargain were also substantively unfair, and as a direct result of the unequal bargaining power. ${ }^{35}$ On the other hand, it may be especially important to prove procedural unconscionability in circumstances where it is hard to judge whether a bargain was substantially unfair, such as when it is difficult to determine what the going rate for such a player actually was and there is a wide margin of error as to substantive unconscionability. Unequal bargaining power is not merely partly

\footnotetext{
$\overline{34}$ See also Lee (2017), pp. 630-3.

35 See Feinberg (1986), pp. 251-2; Wertheimer (1996), p. 51; Burrows (2011), p. 300; (2016), p. 834; Lee (2017), p. 626.
}

constitutive of unconscionability; sometimes, it also signposts, indicates, or suggests the presence of a substantively unfair or unconscionable bargain in cases where substantive unfairness is difficult to judge for some reason. Then again, that the process or circumstances of bargaining were unfair could only ever be prima facie evidence and never decisive evidence of substantive unfairness in the resulting contract.

A further aspect of the doctrine of unconscionable contracts that stands in need of normative theorisation is the idea that it is morally reprehensible to knowingly take advantage of another's weakness. Perhaps courts are more likely to be shocked if the stronger party had knowledge, actual or constructive, of what it was doing. But we must ask: why is it wrong to knowingly take advantage of another party's weakness in a bargaining situation? And, how might this relate to the case of English professional football contracts involving non-English-speaking players?

One thought could be that as soon as one contracting party does know or should know of the weakness of the other contracting party, then the former has a moral duty not to play on the weakness of the latter. However, it is unclear why parties have a moral duty not to play on the weakness of another party in a bargaining situation merely because they have knowledge of the weakness, actual or constructive. For example, arguably there would be nothing reprehensible in itself, other things remaining equal, about a club knowing that the player has no other offers on the table and setting its offer accordingly to get the best deal it can, just as there would be nothing reprehensible in itself about a player knowing that the club is in desperate need of a player to play the left midfield position and in the light of this refusing to accept a low offer from the club. Part of the purpose of bargaining is that it brings together two sides who each want the best possible deal for themselves, producing a result where both sides gain. To require those involved in negotiations to give up the posture of self-interest and take up instead an altruistic attitude seems overly demanding.

Perhaps, then, the moral reprehensibility has something to do with how, or the manner in which, parties go about playing on the weakness of the other side. For example, if the relevant weakness is the inability of the offeree to read the contract, then playing on the weakness would appear to involve a form of deception. To hide or conceal terms in the written contract by omitting to declare them to the other party reeks of dishonesty or bargaining in bad faith, especially if there is no morally relevant difference between acts and omissions when it comes to the vice of dishonesty. ${ }^{36}$ Arguable even a substantively fair contract could be nonetheless procedurally unconscionable if it was procured in a morally reprehensible way-such as if the club does not

\footnotetext{
$\overline{36}$ See Burrows (2011), p. 300; (2016), p. 835.
} 
make plain to the player in his first language the fact that an option clause is unilateral to the club only, especially if the club knows (or should make an effort to know) that the player is signing the contract under the mistaken assumption that he will be able to opt out at the end of the contractual period.

Non-English-speaking players might be taken advantage of in the aforementioned ways (morally reprehensible procedural unconscionability) precisely because the context pits especially poorly informed offerees against highly knowledgeable offerors. ${ }^{37}$ In the words of Football Agent 3: '[If] say you've got an African player moving from a French club to an English club you've got three potential languages, how easy would it be to pull the wool over the eyes of one player?'. ${ }^{38}$

On the other side, if the club does not invest in an interpreter and allows the player's agent to do the translation and interpreting during the negotiations and contract signing, this may put the club at a disadvantage in that they do not have access to how and what information is conveyed to the player, and may not receive accurate and timely information about what the player is thinking and saying. Whether this disadvantage is morally troubling, however, depends on whether one also finds that the club has been responsible for putting itself into this disadvantageous position, despite having the wherewithal to fund independent translators. The same might not be true of players if they are unable to fund these services. We shall return to these issues of responsibility and capacity in Sect. 5.

Note, we are not suggesting that concealment of facts in bargaining situations is always and necessarily morally reprehensible. It may be that a customised ethics of bargaining would permit 'not letting on' to the other party just how desperately one needs what it is they are offering (i.e. bluffing). ${ }^{39}$ Nevertheless, it is another thing to conceal features of the bargain, to attempt to hide terms that one believes the other party might reject if they knew about them. This could be morally reprehensible because it fails to live up to one of the central virtues of bargaining, namely honesty, where lack of honesty puts at risk the continued existence of the valuable social practice of bargaining and the mutual gains that flow from this practice. Therefore, to say that the offerer has a moral duty not to play on the weakness of the offeree could be simply to say that the offerer should refrain from acting deceptively by attempting to hide terms in the contract without declaring them.

However, what about cases where the club did not have knowledge, actual or constructive, of the true extent of the

\footnotetext{
37 cf. Wertheimer (1996), p. 61.

38 Football Agent 3.

39 See Carr (1968).
}

player's lack of English facility? Could there be a credible moral justification for a court deeming the contract unconscionable even in such cases? We believe so. Another way of justifying, both morally and legally, the claim that English professional football contracts signed by players who lack even basic English proficiency can be unconscionable contracts is by arguing that such contracts could fail to respect and realise the autonomy of the players. This strategy invokes the value of autonomy as a basis for both the principle that contracts should normally be respected and the limiting principle that when certain vitiating factors are present contracts should not be respected. The particular form of autonomy at stake here is the capacity to make bargains with others and to create legal obligations based on the formalisation of those bargains. ${ }^{40}$ And so we maintain that a contract respects and promotes autonomy in the relevant sense only if the parties have a reasonable level of comprehension about what it is they are bargaining for. The extreme cases would be non est factum. But perhaps at the less extreme end of this spectrum of autonomy-undermining contracts would be contracts signed by people with significant language deficits. The thought would be that even this lesser degree of diminished autonomy can justify the use of the label 'unconscionable' (morally regrettable) even in circumstances where the clubs lacked knowledge, actual or constructive, of the language deficit.

Along these lines, we reason that when both the negotiations and the contract are in English-as is usually the case in the UK but interestingly not in other European countries where contracts tend to be provided in translation ${ }^{41}$ - this increases the risk that a non-English-speaking player will not have a reasonable level of comprehension about what is being bargained about, and therefore decreases the chances that he will get the legal obligations that he actually wills. This is more than the minimal expectation that the player should have a basic comprehension that he is negotiating about and signing a contract to play professional football for an English club. It is the fair expectation that the player should have an opportunity of achieving a reasonable level of comprehension concerning a sizeable proportion of the negotiations and the contract, or at the very least key parts thereof.

To illustrate, suppose a contract contains an option clause allowing the club to unilaterally extend the contract a determined number of times for similar remuneration, or else contains a provision stipulating that whilst most of the remuneration package will take the form of a monthly wage, a significant proportion will be payments for image rights, and paid to a separate image rights company. If a

\footnotetext{
40 See Fried (1981); (2014); Raz (1982); Chen-Wishart (2014).

${ }^{41}$ Football Agent 2; Football Agent 3.
} 
non-English-speaking player cannot read the contract in English, nor comprehend much of the explanations about the contract offered in English, to know that these clauses and provisions are present, he may end up creating legal obligations other that what he willed. Although the player may have willed the creation of legal obligations around being a professional footballer for an English club for a period of time, he may not have willed the creation of the club's unilateral right to renew the contract and may not have willed the creation of an elaborate tax evasion scheme. ${ }^{42}$

Of course, both clubs and players' representatives will often assert or argue that non-English-speaking players do understand what is going on, and have comprehension of key parts of the contract being signed. But we believe that, both morally and legally, these assertions cannot be taken at face value, but must be scrutinised and, where necessary, challenged. At the very least there should be evidence that adequate language support has been provided to the player.

Of course, at this stage it might be objected that very often even English-speaking players do not pay much attention to contractual negotiations and are only dimly aware of the substance of the contracts they sign having not bothered to read them in full or at all. ${ }^{43}$ Does this mean that all football contracts are unconscionable? However, we would respond to this objection by insisting that at least Englishspeaking players have the opportunity to pay attention to the negotiations and to read the contract they are signing. If they fail to take the opportunity, then they lack actual comprehension, but they do not lack the opportunity for comprehension. In some circumstances, non-English-speaking players may lack both, and this poses a threat to their autonomy which is both different in kind and degree to the challenges faced by English-speaking players in dealing with contracts.

We also note that sometimes the aforementioned lack of opportunity could be partly down to limited English language facility and partly due to the actions of the club. Suppose a player has good enough English to be able to understand the negotiations and even to read the crucial parts of the contract given sufficient time, but the club is imposing severe time constraints on the negotiations and on the reading of the contract-requiring the deal to be done and the contract to be signed in a matter of days, hours, or even minutes ahead of the closing of the transfer window. ${ }^{44}$ This lack of opportunity also fails to respect and promote the autonomy of the player. It could also render the contract procedurally unconscionable irrespective of why the relevant

\footnotetext{
$\overline{42}$ As identified by Football Agent 3, a provision concerning payments for image rights could even render a player liable to criminal prosecution for tax evasion under the Criminal Finances Act 2017.

${ }^{43}$ Football Agent 1.

44 Football Agent 3; Player Liaison Officer 3.
}

time constraints are being imposed-the club might not be imposing the time constraints artificially to take advantage of the weakness of the player, but could itself be reacting to the departure of another player and the need to sign a replacement before the close of the transfer window.

\section{Primary and secondary responsibilities for providing language support}

Thus far, we have argued that if an English professional football club plays on the weakness of non-English-speaking players this could, under certain circumstances, make for unconscionable contracts. However, we might face the objection that by focusing on the conduct of clubs we have only told part of the story. For example, it is one thing to ask how clubs should treat players who cannot speak the language in which negotiations are conducted and the contract is written; it is quite another thing to ask whose responsibility it is in the first instance to ensure that such players do receive the language support they need, such as in the shape of an interpreter present during negotiations and the signing of the contract, and/or the provision of a translated version of the contract. After all, if non-English-speaking players procured for themselves the language support they needed or if their representatives provided professional language support, then this would go a long way to removing the spectre of procedural unfairness, the risk of substantive unfairness, and the threat to autonomy. So some of our ethical arguments above are dependent on our saying something convincing about what an appropriate allocation of responsibilities for providing language support would look like.

First things first, where does the burden of proof rest? Does it rest with the club to show that players or players' representatives have the primary responsibility? Or does the burden rest with the latter to show that the club has primary responsibility? We shall not seek to make arguments that shift the burden of proof in one direction rather than another. Instead, we propose to tackle the issue head on by outlining a substantive normative account of the appropriate allocation of responsibilities for providing language support.

Our account appeals to both capacity-that responsibility tracks whichever party is most capable-and the existence of fiduciary relationships-that responsibility also tracks whichever party has a duty of care. Based on this, we would argue that players' representatives bear the primary responsibility for ensuring players receive the language support they need during contractual negotiations and signing. For one thing, players' representatives are often in the best position to judge whether or not a player needs language assistance, since they know the players better than the club. Certain representatives might also specialise in dealing with unsigned players from particular countries and may have 
local knowledge about who could potentially translate for the players during the early stages of making contact with clubs and starting negotiations. However, to clarify, we are only suggesting here that players' representatives normally have a primary responsibility to ensure that players receive the language support they need, not that representatives have a primary responsibility to act as interpreters themselves. They lack the professional training and independence required for the latter. We shall say more on this in the next section.

That players' representatives have a primary responsibility to provide language support also flows, we believe, from the fiduciary relationship between players' representatives and players - or, more specifically, from duties of care and standards of diligence and integrity that normally define these sorts of relationships. It is generally recognised that players' representatives have a fiduciary obligation to pursue the best interests of their players (duty of care) and to do so with competence (standard of diligence). Arguably, this means ensuring that the client receives the necessary language support when entering into contractual negotiations or signing a contract in a foreign language, either by procuring language support privately or by seeking language support from a national football association or professional players' association.

We note here that English courts accept the basic proposition that players' representatives have at least some fiduciary duties towards the professional players they represent. ${ }^{45} \mathrm{We}$ observe as well that presently English football intermediaries must register, and sign an Intermediaries Agreement, with the FA, in which they agree to the FA Intermediaries Regulations. ${ }^{46}$ Although these regulations do not specifically refer to language difficulties experienced by players, they do include the following general principle: 'A Club, Player, Intermediary or other Participant must not so arrange matters as to conceal or misrepresent the reality and/or substance of any matters in relation to a Transaction'. Failing to arrange for translation/interpreting services could potentially fall foul of this general principle, we believe.

Interestingly, the FA Intermediaries Regulations also require persons seeking to act as intermediaries to satisfy the FA's Test of Good Character and Reputation for Intermediaries. ${ }^{47}$ Presently the Test merely sets out certain disqualifying factors-including, for instance, having unspent criminal convictions, bankruptcy, not being registered or being

\footnotetext{
45 Consider Imageview Management Ltd v. Kelvin Jack [2009] EWCA Civ 63.

46 FA Intermediaries Regulations, July 2017. Available at: http:// www.thefa.com/football-rules-governance/policies/intermediaries/ regulation-and-forms.

47 Available at: http://www.thefa.com/ /media/files/thefaportal/gover nance-docs/agents/intermediaries/31\%20march/test-of-good-chara cter-and-reputation-for-intermediaries.ashx.
}

suspended from registration as an intermediary with the FA. There is no mention of 'duty of care', 'standards of diligence and integrity', and so forth. This surely needs to change. Specifically, we believe there is a pressing need for the FA and/or a voluntary association like the Society of Football Intermediaries and Agents (SOFIA) to introduce a code of conduct for football intermediaries that would formalise the norms of professionalism, the elements of best practice, and the high ethical standards that can be reasonably expected of English football intermediaries, including in relation to the provision of language support for players. For example, such a code might stipulate that it is best practice for agents/ intermediaries to identify the English language proficiency (or lack thereof) of their clients and, if they have capacity, to arrange the provision of interpreters for contract negotiations and signing, or else to call upon the club to make these arrangements, if it has the capacity.

In fact, the above suggestions are not without precedent in related areas. In terms of general fiduciary duties, we note that the Solicitors Regulation Authority (SRA) Code of Conduct states that solicitors must 'act in the best interests of each client' and 'provide a proper standard of service to [their] clients'. ${ }^{48}$ In terms of the provision of language support specifically, we highlight further that the right to an interpreter is enshrined in EU Law for criminal proceedings, ${ }^{49}$ and is part of policy or codes of practice for a range of community interpreting encounters such as in healthcare, immigration, and police contexts. ${ }^{50}$ All of these situations involve institutions which in principle have a duty of care to the people who need interpreting support.

Now we also recognise that such ethical standards have rarely been applied in commercial contexts, within which professional football indubitably sits. At present, there are no policies or codes of conduct promoting the use of interpreters. Indeed, according to Ozolins, partly due to commercial confidentiality rules and the reluctance of such interpreters to go on record, this is the area of interpreting which is the least researched and the least thought about in terms of ethics. ${ }^{51}$ We nevertheless think that this status quo should change.

Specifically, we propose that it is the primary responsibility of players' intermediaries to provide English language support in contract negotiations and signing meetings, provided they have this capacity. It seems highly unlikely that a young non-English-speaking player from a developing

\footnotetext{
48 Available at: https://www.sra.org.uk/solicitors/handbook/code/.

49 Available at: https://www.euromed-justice.eu/en/document/eu2010-directive-2010-64-eu-european-parliament-and-council-20-october-2010-right.

50 Hale (2007).

51 Ozolins (2014), p. 30.
} 
country who is entering into contractual negotiations with an English professional football club for his first ever professional contract would have the financial capacity to procure the services of an interpreter for the relevant meetings and to commission the translation of the contract itself. The same might also be true of players' intermediaries, of course, especially if they are also based in developing countries. Then again, clearly some players' intermediaries are located in Europe and work with top clubs and players on negotiations for very lucrative contracts. It is by no means beyond the financial capacity of these agents/intermediaries to provide language support to players.

The implication, therefore, is that it is the player's representative rather than the club who bears a primary responsibility for ensuring that the player receives the translation/ interpreting services he needs. But what follows from this? Would it absolve the club of moral blame for taking advantage of the weak position of the player in circumstances where the player's representative had failed to ensure that adequate translation services were on hand? Would it show that the club has no responsibilities whatsoever to provide language support during contractual negotiations and signing meetings? We believe that the correct answer to both questions is negative.

First, the fact that the player's agent or intermediary had a primary responsibility to provide the language support-and failed to do so-does not necessarily absolve the club of moral blame for having taken advantage of this weakness or for having exploited the player, if indeed that is what it has done. That the club did not actually cause the weaknessi.e. that it did not fail to discharge a primary responsibility to provide language support-does not necessarily excuse the act of offering a substantively unconscionable contract (one-sided or harsh terms) or the act of violating the player's autonomy (terms that do not reflect the will of the player).

Second, and this follows on from the first point, even if the club does not have a primary responsibility it might yet have a secondary responsibility to provide translation and interpreting services. We believe that in situations where players' representatives either are unable or unwilling to provide the necessary language support, the relevant clubs have secondary responsibilities to provide this support, whenever they are capable of doing so. This might include procuring the services of an interpreter during contractual negotiations and signing meetings, as well as paying for the contract to be translated into the player's first or even second language. In the case of standard form contracts, clubs may be able to pool some of these costs, of course. Indeed, once a contract has been translated into a given language, provided there are no significant changes to the contract—-besides the terms of the salary and one or two other key variables (e.g. option clauses)-there may be little marginal cost in producing each new copy for other players.
But what if the club is also either unwilling or unable to provide language support? Here again secondary responsibilities should track capacity and fiduciary relationships. And so other organisations and institutions such as national football associations or players' unions or professional players' associations might also have secondary responsibilities. In situations where players' intermediaries and clubs have both failed to fulfil their primary and secondary responsibilities, respectively, it means that these other organisations could bear responsibility as providers of last resort.

Nevertheless, this last point is not meant to detract from the fact that if clubs have the capacity to provide the necessary language assistance, then they ought to do so. That being said, capacity is not simply about whether the club has the brute financial capacity of procuring language assistance for the player and commissioning a translation/ an interpreter-all in the required time frame to meet its deadlines. It is also a matter of what a club can do without incurring unreasonable burdens. What constitutes an unreasonable burden must be open to debate. The devil is always in the detail. But it seems plausible to say that for a wealthy top-flight club spending relatively small sums of money on translation/interpreting services-in comparison with the salary and the signing on fee being paid-would not be an unreasonable burden, either measured by the club's strong financial position or by what it potentially stands to gain from signing the player. Then again, in these instances players or players' intermediaries might also be wealthy enough to pay for the services, so the club may not have to.

Naturally the crunch point comes at the lower end of the professional game, where clubs are struggling to make ends meet and to clear debts. If they are in a position of hiring several untested migrant players every year on oneyear deals, most of whom do not end up being good investments, then it might be unreasonable to expect these clubs to pay for translation/interpreting services, based on their precarious financial position and the expected limited gains from signing these sorts of players. Nevertheless, that poorer clubs lack the capacity to provide such services once again would not necessarily absolve them of moral blame for taking advantage of this weakness or exploiting the player (e.g. violating the player's autonomy), if indeed that is what they have done. The morally right thing to do under such circumstances would be to call in other organisations and institutions such as the FA or the PFA to provide the services. Where this is impossible or impractical, and there is no other option, poorer clubs might simply have to refrain from attempting to sign players whom they have reason to believe are unable to comprehend the negotiations and read the contracts and are not receiving adequate translation/interpreting services from other parties. For wealthier clubs, by contrast, their responsibility would be to provide translation/interpreting services should the player's representatives fail to do so. 


\section{Player representatives as unqualified interpreters and the ethical principles of interpreter codes of practice}

That it appears to be common practice for the player's representative to play the role of an ad hoc unqualified interpreter in negotiations and contract signing-in the absence of a qualified interpreter-shows that the language industry, and the translation and interpreting discipline, has not yet managed to educate users in the football industry of the value of professional interpreting. This is also the case in a whole host of other professional domains because interpreting is not viewed by society as a professional skill in the way medicine or law, for example, is. Interpreting is generally associated with an innate ability to speak a language rather than with a qualification that requires education and training, and adherence to professional codes of conduct. This leads to a widespread misapprehension that someone who can speak a language can translate and interpret. ${ }^{52}$ Consequently, the use of unqualified ad hoc interpreters is increasingly common to meet the rising needs of multilingual societies, in the football industry ${ }^{53}$ as elsewhere. ${ }^{54}$

Interpreter codes of practice exist in contexts where the majority of professional interpreting has traditionally been undertaken, namely conference interpreting (simultaneous interpreting at, for example, the UN or NATO) and community interpreting (dialogue interpreting in healthcare and police settings, for example). These codes of practice generally contain the following ethical principles: professional competence and integrity which are standard principles for all professions; confidentiality; neutrality/impartiality; and fidelity. All of these principles have been regularly challenged and debated by a wide range of interpreting practitioners and scholars, examining the gamut of contexts in which interpreters work. ${ }^{55}$ The most common theme in research into interpreter ethics is that of interpreters identifying a disjunction between ethical principles espoused in codes of practice and the realities of professional interpreters' daily work and the expectations they are subject to, such disjunctions being greater in less structured events such as business negotiations than they are in highly regulated and codified settings such as in a court of law. ${ }^{56}$ Although the 'interpreters' we are interested in here are not professionals, similar gaps between ethical principles and practice are

\footnotetext{
52 Mikkelson (1996); Rudvin (2007).

53 Lavric and Steiner (2012).

54 Schouten et al. (2012); Pérez-González and Susam-Saraeva (2012).

55 Hale (2007); Inghilleri (2011); Ozolins (2014); Setton and Prunč (2015).

56 Ozolins (2014), p. 31; Setton and Prunč (2015), p. 147.
}

evident. Individuals playing the dual role of player representative and unqualified interpreter have no professional interpreting obligations to respect. Indeed, they are unlikely to have any knowledge of interpreter codes of conduct. Their clients can thus have no expectation that the person undertaking the interpreting is providing a professional service.

Professional competence means an interpreter being committed to high standards of performance, and ensuring s/he has the appropriate skills and knowledge for the interpreting task. The consequence of a non-professional adopting the interpreting role in the contexts we are exploring can be that his/her proficiency in English as a foreign language and his/her proficiency in interpreting can vary greatly. We also note, for example, accounts of negotiations proceeding using Google translate, ${ }^{57}$ a tool that can be effective for simple non-technical stretches of language, but is distinctly limited when dealing with the complex technical language typically found in contracts.

We will look at integrity and neutrality/impartiality together. Integrity includes honesty, such as 'avoiding or declaring conflicts of interest, and deriving no personal gain from information obtained in the exercise of the profession' ${ }^{58}$ There is no doubt that individuals adopting the dual role of player representative and unqualified interpreter have a conflict of interest in their interpreting work and so their integrity as interpreters can be questioned, as indeed can their neutrality/impartiality. Impartiality as a professional stance to be adopted by interpreters denies interpreters agency and visibility and is challenged by a wide range of scholars who demonstrate that there are many circumstances, in many contexts, where interpreters cannot be impartial and/or invisible, where they need to employ clarifying, cultural brokering, or even advocating strategies to counter power imbalances. ${ }^{59}$ It is interesting to note professional business interpreter Karansiou's observation that 'in high-level business interpreting negotiations there are usually two interpreters representing the interests of each side ${ }^{60}$ In other words, when the stakes are high, both parties ensure they have a professional linguist mediating on their side to counter the risk of a lack of neutrality in the interpreting - a risk that is to be expected.

Therefore, that there should usually only be one person interpreting in football contract negotiations and signing meetings and that $\mathrm{s} / \mathrm{he}$ should be representing the player are surprising. The club may be saving money by not paying for a professional interpreter, but it potentially ends up with a less beneficial deal because the interlingual communication

\footnotetext{
57 Football Agent 1; Football Agent 3.

58 Setton and Prunč (2015), p. 146.

59 Angelelli (2006); Barsky (1996); Inghilleri (2011).

${ }^{60}$ Cited in Downie (2016), p. 11.
} 
is controlled by the player's representative(s). The intense media interest in the football industry and the huge wages earned by players mean that clubs are highly protective against outsiders, ${ }^{61}$ and outsiders would include interpreters. Consider this insight from Player Liaison Officer 7, commenting on the use of professional interpreters in contract signing meetings:

When you bring in external translators (sic) there's an ethos within the club, there's a psychology within the club, there's all kinds of things running within the club that you want to keep within the club. It's the way we do it, it's our nature. When players come in we recruit with that in mind so you don't want to be giving away too many of your secrets outside of the club. ${ }^{62}$

In contract signing situations, in the absence of professional codes of conduct which provide a framework of impersonal professional trust-namely an obligation to adhere to good practice, expert knowledge and competence, lack of personal or institutional bias, and maintenance of confidentiality - the club, and indeed the players, have to, and do, rely on personal trust and established relationships in order to protect their interests. ${ }^{63}$ This practice also enables clubs to protect the confidentiality of the negotiations, thereby addressing another of the standard principles of interpreter codes of practice. It is probable that in some contract negotiations this trust is misplaced.

Ozolins, in his review of interpreting research notes that the little research there is into business/commercial interpreting indicates an approach focussed on getting business done, on communicative efficiency, rather than on the kind of concern for accuracy of interpreting that is highly valued in legal contexts, for example. ${ }^{64}$ Interestingly, work on the interpretation of press conferences in Formula 1 motor racing and at European football championships also finds that the rendition of the essentials is sufficient for users to feel that quality interpreting has been delivered. ${ }^{65} \mathrm{~A}$ focus on communicative efficiency can lead to interpreters going against codes of ethics, not least the fidelity principle they obey in other interpreting settings-including summarising or expanding text, or censoring messages to avoid conflicts arising which could derail negotiations ${ }^{66}$ - thus providing an example of how the principle of neutrality could be tested in

\footnotetext{
${ }^{61}$ Football Agent 3, especially comment quoted above about people preying on players.

62 Player Liaison Officer 7.

63 See Edwards et al. (2006), p. 90, concerning how migrants prefer family members as interpreters in health consultations.

64 Ozolins (2014), p. 30.

65 Sergio (2003), p. 170; Sandrelli (2012), p. 99.

66 Takimoto (2006).
}

the interpretation context of negotiations over a professional footballer's contract.

The pragmatic communicative efficiency that is in evidence in how the interpreting can be conducted in business contexts, and indeed in sporting contexts, is reflected in the club's pragmatic use of the player's representative to undertake any interpreting. Hiring an interpreter costs money and, as noted by Football Agent 1: 'Football clubs tend not to spend money on things unless they have to, even at the highest level'. ${ }^{67}$ It is quite simply cheaper for a club to use the player's representative as interpreter in contract negotiations and contract signing meetings. It also makes practical sense for the club to allow the player's representative to look after the interpreting because there will usually be an established relationship between the player's representative and the player and thus an established channel of interlingual communication.

In fact, there are several reasons why not using professional interpreters in contract negotiations and signing meetings has become normalised or conventional practice:

- clubs might assume (rightly or wrongly) that all the interpreting work has already been done behind the scenes;

- lack of appreciation and value placed on professional interpreting skills by clubs;

- a 'getting the job done' pragmatism whereby available resources (often the intermediary/agent) are used to interpret, which saves using scarce resources on hiring professional interpreters;

- a mistrust of outsiders in general which is amplified in confidential contract negotiation and signing sessions;

- ignorance of the fact of the true extent of the player's lack of English skills, including where a player's silence is misinterpreted as comprehension plus acquiescence;

- a high turnover of managers and of recruitment staff might inhibit the development of a long-term policy or set of rules within the culture of each club;

- a principled view that it is the responsibility of the player and his representative(s) to provide translators/interpreters;

- a vested interest in not providing translators/interpreters because of a perception that this makes it easier to control the player and get what the club wants.

Despite the convention of agents/intermediaries looking after any translation/interpreting needs, we believe that partly because contract negotiations and signing meetings in professional football are potentially very lucrative commercial events, where the stakes can be very high, clubs would benefit from the presence of translators/interpreters. After

$\overline{{ }^{67} \text { Football Agent } 1 .}$ 
all, in order to protect themselves against being unable to enforce contracts against players (having the player escape the contract) because the contract is unconscionable, clubs would be well advised to check whether the player has proficient English (and either insist that the player attends the contract signing meeting with an interpreter hired by the player or if necessary provide access to an interpreter hired by the club, or a neutral body) or to themselves produce a version of the contract in the first language of the player. If so, then clubs could not be accused of knowingly taking unfair advantage of the fact that the player was unable to read and comprehend the language in which the contract was written.

We set out our recommendations more fully in the next section.

\section{Practical recommendations}

Drawing on the above, we now make a series of recommendations for each of the stakeholders in professional football contracts. Our first recommendation is that:

- ideally there ought to be present two qualified interpreters, one provided by each negotiating party. ${ }^{68}$

This stems from our understanding that it is just as possible for the club to be in the dark and for the player's intermediary/agent and the player to be manipulating the negotiations in their own favour. This alone provides an economic reason for clubs to employ their own interpreters rather than rely on players' agents/intermediaries.

Our second set of recommendations concern what agents and intermediaries, in particular, should do to protect their clients. They should:

- if they have the capacity, assess the language needs of their clients and provide translation/interpreting services during negotiations and contract signing meetings;

- join relevant intermediaries associations and sign up to those associations' code of conduct;

- lobby the relevant association and the industry as a whole to make sure that checks are being done as to compliance with the code of conduct.

For their part, intermediaries associations should:

- establish a code of conduct including a clause on the provision of English language support, calling on intermediaries to procure the services of translators/interpret-

${ }_{68}$ See also Pym (1992), pp. 152-3. ers during contractual negotiations and contract signing meetings, and to purchase translations of contracts if not translated by clubs, where they have this capacity.

Our third tranche of recommendations have to do with what clubs should do if intermediaries fail to act. We believe they should:

- identify whether or not the player is a native speaker of English;

- make robust enquiries as to whether the intermediary/ agent is providing adequate English language translation/ interpreting to the player, which will involve not taking the player's silence at face value;

- if they have a reasonable suspicion that the player is not being adequately assisted, they should provide, where necessary, translation/interpreting services to the player during contractual negotiations and signing sessions, if they have the capacity;

- produce versions of the contracts in the first language of the player, as is practice in many European countries, once again if they have the capacity.

Our final group of recommendations pertain to situations in which neither the player's representative(s) nor the club have either the inclination or the capacity to offer language services:

- one or both of these parties should seek the presence of a neutral interpreter provided by an independent body, such as a national football association, players' union or professional players' association, at the very least for the contract signing meeting.

For their part, these independent bodies should also be:

- prepared and willing to act as last resort providers of English language support;

- proactive in ensuring that players have access to neutral interpreters/translators, even in circumstances where neither intermediaries nor clubs are willing to flag up the issues to them or make requests on behalf of players;

- pursue the avenue of putting players who are in the process of negotiating and signing contracts in contact with other players who are further along in their careers but who have themselves been through the same processes and have had the same language challenges, so that they can share their experiences of the pitfalls and how to avoid them.

Importantly, the above recommendations are not only about protecting the club's interests, and about upholding ethical values in the applied practice of translation, but 
also about protecting the player from exploitation. Thus, in earlier sections we argued that because of language barriers, non-English-speaking players could end up signing unconscionable contracts, if not based on procedural or substantive unfairness, then potentially based on violations of their autonomy. Whilst clubs may find themselves at a disadvantage in the negotiations because the player's representative(s) can control all the communication across language barriers, the player is often also entirely dependent on his representative(s). We end with the words of a former migrant player which poignantly illustrates this last problem:

It was done in English so I remember the first one from Italian Serie A club to EPL club, that was done in English so, again, I couldn't understand. I trusted my agent to make sure he gets me the right contract. Again, I think if I had understood the contract I could have had some objections about the terms and the objectives of the contract because I wasn't very happy afterwards. An interpreter or someone in a way who could understand the contract that would have greatly helped. It would have allowed me to make an informed decision and whether I think that contract is suitable for me or not rather than giving blind trust to an agent which I don't know whether they are working for my interest or for the club's interest or for his own interest. ${ }^{69}$

Acknowledgements The article was presented at the UEA Ethics Forum in 2018, with thanks to all those who attended. We are also grateful to Gareth Spark for providing insights and crucial input at an early stage of this article. Finally, we would like to thank the journal's two anonymous reviewers for several helpful suggestions and corrections.

OpenAccess This article is distributed under the terms of the Creative Commons Attribution 4.0 International License (http://creativeco mmons.org/licenses/by/4.0/), which permits unrestricted use, distribution, and reproduction in any medium, provided you give appropriate credit to the original author(s) and the source, provide a link to the Creative Commons license, and indicate if changes were made.

\section{References}

Angelelli CV (2006) Revisiting the interpreter's role: a study of conference, court, and medical interpreters in Canada, Mexico, and the United States. John Benjamins, Amsterdam and Philadelphia

Baines R (2013) Translation, globalization and the elite migrant athlete. Translator 19:207-228

Barsky RF (1996) The interpreter as intercultural agent in convention refugee hearings. Translator 2:45-63

Barry M et al (2016) Research handbook of employment relations in sport. Edward Elgar, Cheltenham
Brown A (2015) Principles of stakes fairness in sport. Polit Philos Econ 14:152-186

Burrows A (2011) Law of restitution, 3rd edn. Butterworths, London Burrows A (2016) A casebook on contract law, 5th edn. Hart, Oxford Carr AZ (1968) Is business bluffing ethical? Harv Bus Rev 143:159

Chen-Wishart M (2014) The nature of vitiating factors in contract law. In: Klass G et al (eds) Philosophical foundations of contract law. Oxford University Press, Oxford

Corlett JA (2013) Economic exploitation in intercollegiate athletics. Sport Ethics Philos 7:295-312

Downie J (2016) Being a successful interpreter. Routledge, London

Edwards R, Alexander C, Temple B (2006) Interpreting trust: abstract and personal trust for people who need interpreters to access services. Sociol Res Online 11. http://www.socresonline.org.uk/11/1/ edwards.html. Accessed 20 Oct 2017

Feinberg J (1986) Harm to self. Oxford University Press, Oxford

Fried C (1981) Contract as promise. Harvard University Press, Cambridge

Fried C (2014) The ambitions of contract as promise. In: Klass G et al (eds) Philosophical foundations of contract law. Oxford University Press, Oxford

Hale S (2007) Community interpreting. Palgrave Macmillan, Basingstoke

Inghilleri M (2011) Interpreting justice: ethics, politics and language. Routledge, London and New York

Kennedy P, Kennedy D (2016) Football in neo-liberal times: a marxist perspective on the European Football Industry. Routledge, Abingdon

Lavric E, Steiner J (2012) Football: le défi de la diversité linguistique. Bulletin suisse de linguistique appliquée 95:15-33

Lee B (2017) Knocked unconscionable: college football scholarships and traumatic brain injury. George Wash Law Rev 85:613-644

Loland S (2015) Fair Play. In: McNamee M, Morgan WJ (eds) Routledge handbook of the philosophy of sport. Routledge, London

Mikkelson H (1996) The professionalization of community interpreting. In: Jérôme-O'Keeffe A (eds) Global vision: proceedings of the 37th annual conference of the american translators association. American Translators Association, Virginia

Ozolins U (2014) Descriptions of interpreting and their ethical consequences. FITISPos Int J 1:23-41

O'Leary L (2017) Employment and labour relations law in the Premier League, NBA and International Rugby Union. T.MC. Asser Press, The Hague

Pérez-González L, Susam-Saraeva S (2012) Non-professionals translating and interpreting: participatory and engaged perspectives. Translator 18:149-165

Pym A (1992) Translation and text transfer: an essay on the principles of intercultural communication. Peter Lang, Frankfurt am Main

McNamee M (2010) The ethics of sport: a reader. Routledge, London

Raz J (1982) Promises in morality and law. Harv Law Rev 95:916-938

Rosca V (2011) Corporate social responsibility in English football: history and present. Manag Mark 6:327-366

Rudvin M (2007) Professionalism and ethics in community interpreting: the impact of individualist versus collective group identity. Interpreting 9:47-69

Sandrelli A (2012) Interpreting Football Press Conferences: The FOOTIE Corpus. In: Kellett Bidoli CJ (ed) Interpreting across Genres: Multiple Research Perspectives. EUT Edizioni Università di Trieste, Trieste, pp 78-101

Schouten B, Ross J, Zendedel R, Meeuwesen L (2012) Informal interpreters in medical settings. Translator 18:331-338

Schubert S, Lopez Frias F (2017) Walk the talk: financial fairness in European club football. Sport Ethics Philos. https://doi. org/10.1080/17511321.2017.137170 (online first)

${ }^{69}$ Former Migrant Player 2. 
Setton R, Prunč E (2015) Ethics. In: Pöchhacker F (ed) Routledge encyclopedia of interpreting studies. Routledge, London and New York, pp 144-148

Slayton P (1976) The Unequal bargain doctrine: lord denning in Lloyds Bank v. Bundy. McGill Law J 22:94-109

Straniero Sergio F (2003) Norms and quality in media interpreting: the case of formula one press conferences. Interpret Newslett $12: 135-165$

Takimoto M (2006) Interpreters' role perceptions in business dialogue interpreting situations. Monash Univ Linguist Pap 5:47-57

Wertheimer A (1996) Exploitation. Princeton University Press, Princeton

\section{Interviewees}

Football Agent 1 (interviewed 27/07/2015)

Football Agent 2 (interviewed 06/07/2017)

Football Agent 3 (interviewed 17/11/2017)

Former Migrant Player 2 (interviewed 11/10/2017)

Player Liaison Officer 3 (interviewed 30/10/2017)

Player Liaison Officer 7 (interviewed 14/11/2017)

Publisher's Note Springer Nature remains neutral with regard to jurisdictional claims in published maps and institutional affiliations. 